\title{
Acceptance of the 2003 John Howland Award: A Journey in Clinical Research
}

\author{
DAVID G. NATHAN
}

Thank you, Fred, for that fulsome description of my efforts to meet the standards of Charles A Janeway, a Howland awardee, whom we both served with such admiration and respect. Of course, no one knows more than you about the leadership of Children's Hospital in Boston. You have been the right arm of no less than five chiefs of our Department. You have been best described by Gary Fleisher, our present chief, of what you, Bill Berenberg, Fred Rosen, and I have always called Dr. Janeway's department. Gary's first act as chair was to reappoint you as vice-chair of the department. Shortly thereafter, Gary called me to tell me that he had made a discovery. "For all these years," he said, " I thought you were an incredible chair. Now I realize it's all Fred Lovejoy."

Fred, you are the very soul of our department and a model of decency and loyalty to excellence for every student, house officer, and faculty member who knows you. Of course, I am deeply honored to receive the John Howland Award. It is the highest honor in academic pediatrics, but to receive it because you have nominated me is even more gratifying, and how this moment would please Charles A Janeway. We are both convinced that somehow, someway, he knows about our relationship and this heart-warming event.

It is customary for Howland awardees to reminisce about their careers with the hope, however vain, that somewhere in this vast room there is someone other than my dear and devoted wife, Jean, who will remain awake long enough to learn anything from such maundering. That touching faith and the convenient contraction of the memory of the elderly forces me into the accepted format.

My father wanted to be a physician. In fact, he was admitted to the Harvard Medical School in 1920, but my grandfather would have none of it. "No son of mine," he intoned, "is going to be a useless doctor. They come to your house to drink your coffee and they don't do a damned thing for you. My son will be an honest business man." Being a dutiful son, my father entered the business world, but he didn't give up his dream. It was transferred to me. Paul Starr writes of my grandfather's viewpoint in his insightful book, The Social Transformation of American Medicine (1). My grandfather's opinion of physicians was very representative of his times. In the preantibiotic era, doctors sat at the bedside watching the patient, drinking their coffee, and doing very little. All that changed with the

Correspondence: David G. Nathan, M.D., Dana-Farber Cancer Institute, 44 Binney Street, Boston, MA 02115, U.S.A.; e-mail: david_nathan@dfci.harvard.edu

Presented at the 2003 Annual Meeting of the Pediatric Academic Societies, Seattle, Washington, U.S.A.

DOI: 10.1203/01.PDR.0000132816.06344.EA discovery of sulfanilamide and penicillin. By the end of World War II, the biomedical revolution had begun and my grandfather's view of medicine was on its way to obsolescence. Academic medicine was to become a bastion of biomedical science. This change is important to us today at this celebration because John Howland was part of the Osler tradition. William Osler had no interest in laboratory-based or high-tech medical research. He believed that physicians should make an academic contribution by careful annotation of even more careful patient observations. Osler's view notwithstanding, Vannevar Bush's 1945 white paper entitled "Science the Endless Frontier" (2) formalized the changed future of academic medicine. Bush, commissioned by Harry Truman, recommended a sustained investment by the federal government in basic research in universities. He thought that applied research (and clinical research is certainly a form of applied research) should be performed in government laboratories like Los Alamos or Brookhaven and in pharmaceutical companies, and so the sleepy campus of the National Institutes of Health on the Wilson estate in Bethesda began to stir; but Congress did not entirely accept Bush's advice. The members agreed to fund basic science in universities, but they had constituents who wanted their chronic diseases cured. The advocacy groups that we know so well today represented the patient/constituents. They demanded disease-oriented clinical research. Now there are 20 different National Institutes of Health-Institutes that offer hope to patients with particular disorders. The National Institute of Child Health was created in 1962 in response to such advocacy. A huge and ever-increasing flow of extramural grants to universities to support both basic and clinical research began (Fig. 1). In 1960, the entire extramural budget of National Institutes of Health directed to US medical schools was about $\$ 250$ million. Today, the total budget it is rapidly approaching \$20 billion - an 80-fold increase in the absolute dollar investment and a 10-fold increase in constant dollars. The enormous growth of the fraction apportioned to US medical schools is shown here. The third bar of each cluster of three shows the logarithmic increase in the expense budgets of our medical schools. The middle bars in the clusters of three represent the growth of research grant income to the schools, and the left-hand bars represent the contributions from $\mathrm{Na}$ tional Institutes of Health. A third of those National Institutes of Health-derived dollars supports clinical research (3). Note the massive growth of the medical school expense budgets, but also observe that in 1960, fully half of the relatively tiny expense budget of all of our US medical schools was met by National Institutes of Health grants. That ratio has progres- 


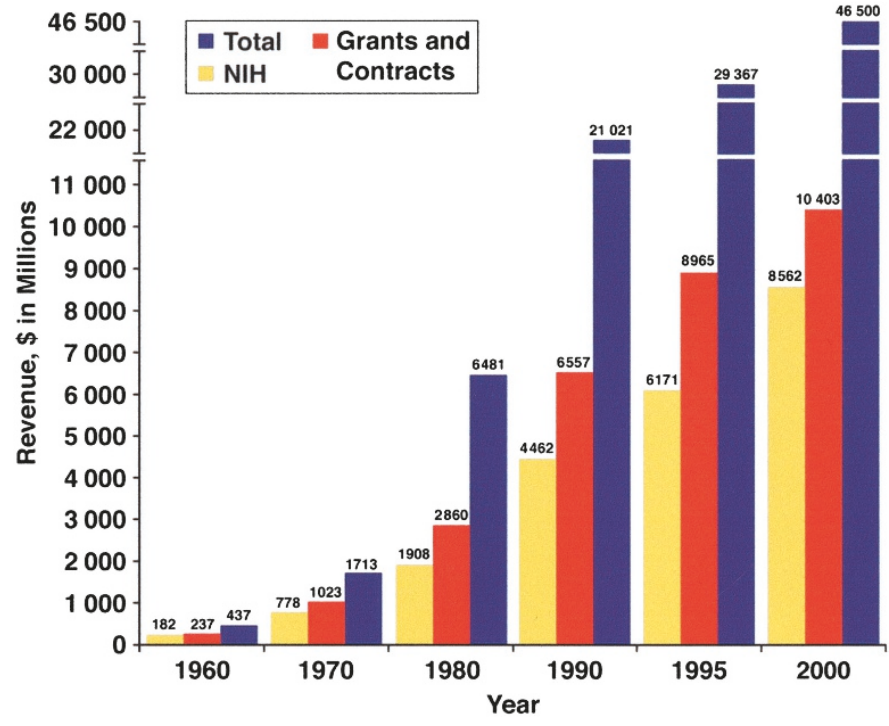

Figure 1. The growth of revenues of US medical schools from 1960 to 2000 . The data do not include the revenues of independent teaching hospitals. Note that total grants and contract revenue has progressively fallen as a percentage of the vastly increased total revenue.

sively fallen. The uncertain income derived from health insurance has uneasily made up the difference.

Medical research investigators of my era were the direct beneficiaries of this incredible if unstable rate of growth. I was a particularly fortunate legatee. During my era, Children's built one new research building, and then, with the help of the Howard Hughes Research Institute, nearly doubled its size. Dana Farber Cancer Institute, our close ally, built three new buildings, and today Children's is building another. Indeed, the national bird of academic medicine is the crane. Everywhere around us, labs and new hospitals are going up. We are borrowing billions to pay for all this. My grandfather, who distrusted us so much, would be horrified because we are counting on philanthropy and a stock market recovery to help us pay the debt. Will donors and Wall Street be there for us in the future?

I graduated from Harvard Medical School in 1955, when the growth explosion was just beginning. The Korean War was winding down, but the doctor draft was very much alive. I had 1 year of internship in internal medicine in a particularly Dickensian Harvard teaching hospital, the Peter Bent Brigham (Fig. 2), a structure rivaled only by its neighboring Children's Hospital (Fig. 3) for outmoded research and clinical facilities. At the Brigham, I was influenced by Samuel A Levine, the great clinical cardiologist of his era, who taught me to worry about my patients all of the time. "If you worry," he urged, "a good idea will come to you." I have been worrying about them ever since.

Following internship, I chose so-called military service at National Institutes of Health in Bethesda, where I started my real clinical research training in the brand new 510-bed General Clinical Research Center then called Building 10 (Fig. 4). I couldn't believe my eyes. In this magnificent building were modern research beds and gleaming labs filled with every possible piece of clinical and scientific equipment and staffed by physicians and basic scientists who knew how to use them. I received ultramodern training and was actually ordered into hematology by my section chief, who told me that I would be a hematologist because he had four stripes on his sleeve and I had two. I remained a National Institutes of Health hematologist for 2 years and there began my career-long interest in disorders of the blood.

Equipped with primitive notions about how to obtain informed consent of patients for clinical research-none of which would be acceptable today - I returned to Boston, completed a year of senior residency in medicine, and plunged immediately into my field.

As I began to work in hematology at the Brigham, where I remained mercifully unfettered for nearly 7 years, the proxim-

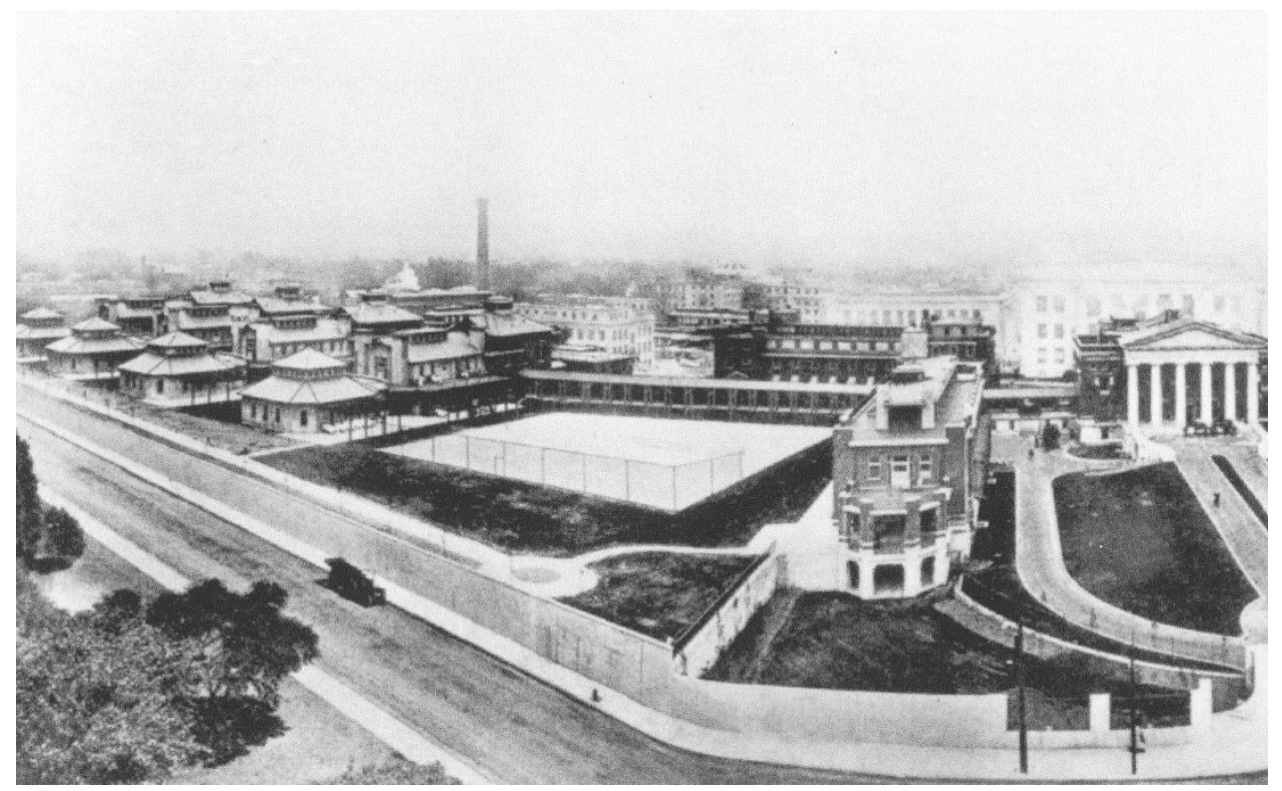

Figure 2. The Peter Bent Brigham Hospital in the early 1950s. Used by permission from Brigham and Women's Hospital, Boston, MA. 


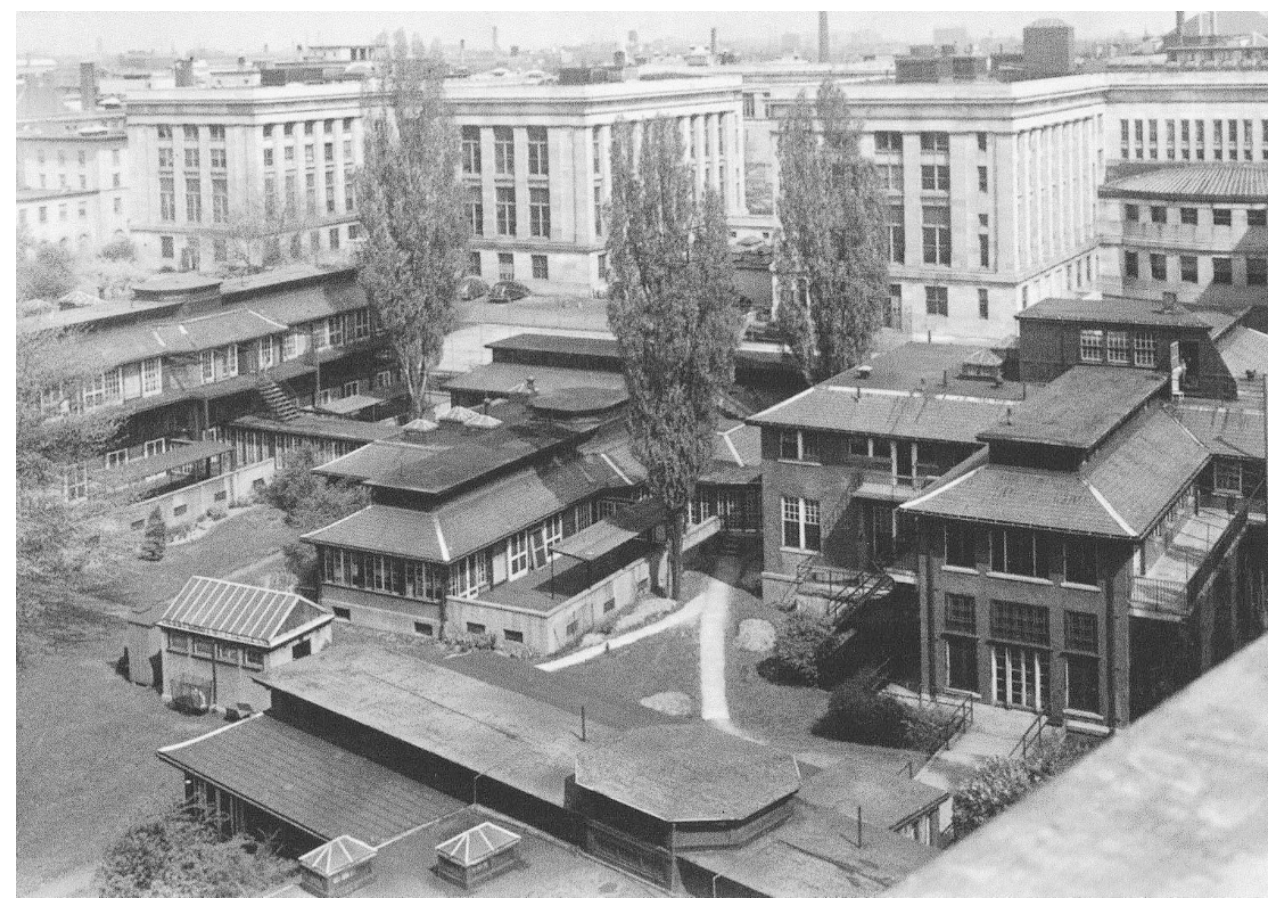

Figure 3. The Children's Hospital wards in the early 1950s. Used by permission from Children's Hospital Archives, Boston, MA.

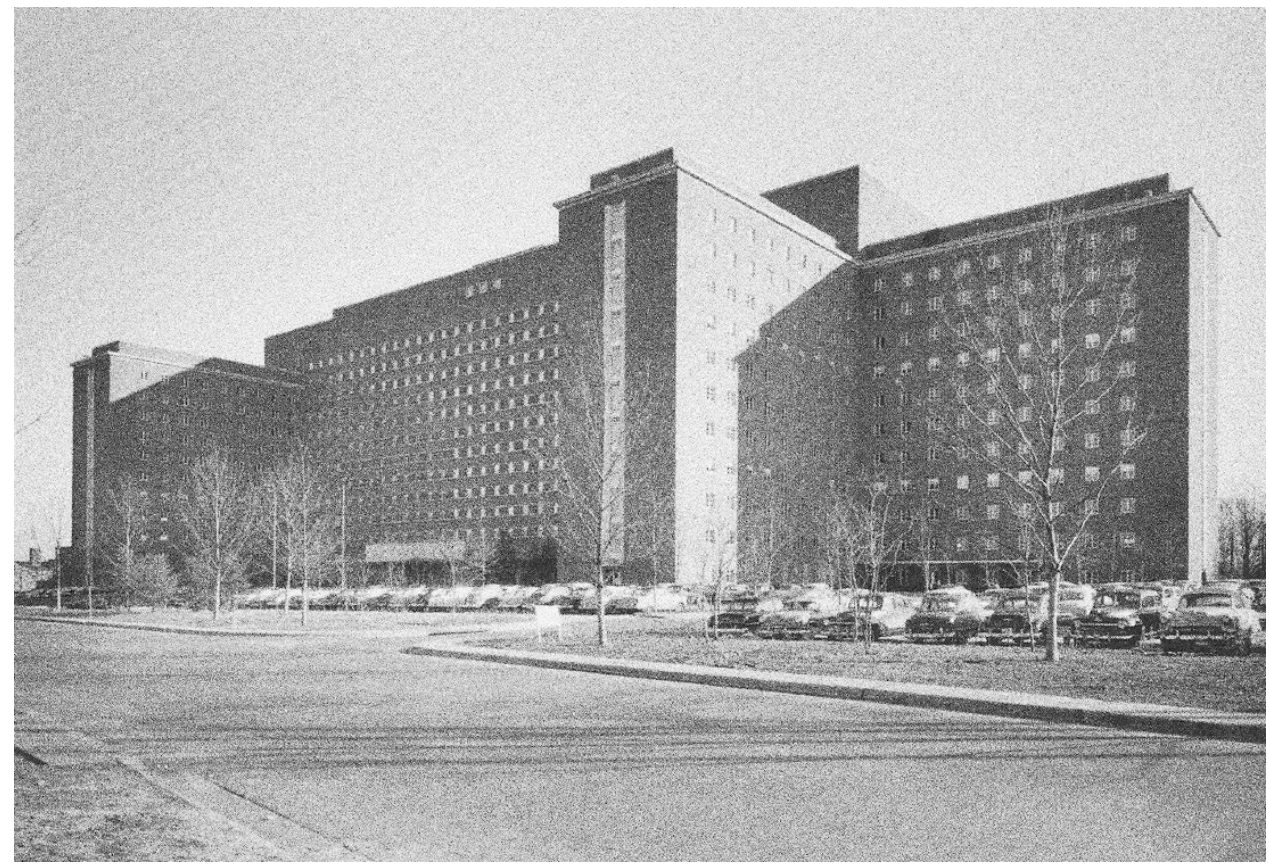

Figure 4. Building Ten (The Clinical Center) of the National Institutes of Health in the 1950s.

ity of Children's Hospital began to reshape my life. The grandmaster of pediatric hematology and Howland awardee, Louis K. Diamond, was beginning to doubt the safety of splenectomy for hemolytic anemia in children (4). He was gathering evidence that splenectomized children might be very susceptible to death from overwhelming sepsis. As usual, he proved to be correct. Dr. Diamond decided to send me patients who might be eligible for splenectomy so that I could perform a red cell survival and splenic scan to be sure that the operation would be useful. Nuclear medicine departments were unknown at the time. Howard Pearson, the Howland Awardee of 2002, had left Children's for greener pastures (and there were few pastures that were not greener than Children's, at least with respect to salary), so Dr. Diamond's agent for many of these consultations became Frank Oski. Frank introduced me to one puzzling and fascinating case after another (5-10), cases that led me to a better understanding of the role of cation balance in the lifespan of the human red cell (11-14). We struck up an enduring friendship and collaboration that culminated in our textbook entitled The Hematology of Infancy and Childhood (15), now going into its sixth edition. I miss Frank so very much. He would have been a Howland Awardee, I am sure. To 
him I owe my commitment to pediatric hematology and to general pediatrics.

Dr. Diamond was also interested in thalassemia because he was fundamentally interested in genetics. His very bright fellow, Park Gerald, began to send me adult patients with thalassemia intermedia, and they began to capture my full attention. In fact, Robert Gunn, a Harvard medical student and now the chair of physiology at Emory, and I made what I thought was a unique discovery on one of Dr. Diamond's patients. We showed that the red cells of splenectomized patients with $\beta$ thalassemia had precipitates of what we were sure were $\alpha$ globin chains in their red cells (16). The huge deposits that damage the cells and cause their instant destruction are shown in Fig. 5. Suddenly we had an insight. Thalassemia is not simply a failure to make $\mathrm{Hb}$; it is a disease characterized by unbalanced protein synthesis. The production of unstable, unmatched $\alpha$ globin, not just the failure of $\beta$ globin synthesis, actually puts the quietus to the thalassemic red cell. Before that observation, Tom Gabuzda and I had observed the puzzling phenomenon that the life span of $\mathrm{Hb} \mathrm{F}$ in the circulation of an untransfused patient with thalassemia intermedia is much longer than the life span of $\mathrm{Hb} \mathrm{A}$, or $\mathrm{A}_{2}$, as shown by the blue lines overlying the inclusion-bearing red cells (17-19). The inclusions solved the puzzle. $\mathrm{Hb} \mathrm{F}$ is variably distributed in the red cells of patients with thalassemia. Cells rich in $\mathrm{Hb} \mathrm{F}$ survive longer because $\gamma$ globin chains combine with free $\alpha$ chains to form $\alpha 2 / \gamma 2$ or $\mathrm{Hb} \mathrm{F}$ (20). From these studies and others, thalassemia investigators came to understand that a pathway to improved therapy could be found by investigating ways to prevent the fetal switch from $\gamma$ to $\beta$ chains. Induction of increased $\gamma$-chain production would prevent toxic $\alpha$-chain precipitation. One product of that research is hydroxyurea for sickle cell anemia $(21,22)$.

We now appreciate that protein precipitation causes many serious diseases from sickle cell disease to multiple myeloma to Alzheimer's disease and mad cow disease. Thalassemia began that appreciation.

In 1966, while much of this work was in progress, Dr. Diamond and his wife, Flo, decided to move to California to join their children. Charles A Janeway, urged on by Fred Rosen, himself a master clinical investigator, invited me to join the hematology division with the idea that I would become the division chief when Dr. Diamond left. In my first meeting with Dr. Janeway, he tried to assure me that I could make the transition to pediatrics from internal medicine because he had done so. I was not impressed-Dr. Janeway was amazingly intelligent. It was not clear to me that I would have the ability to learn a new clinical discipline as complex and exacting. After all, I am a clinical investigator. Patients inspire my research, and one cannot usefully study patients without excellent clinical skills. Furthermore, nearly all of my colleagues except Fred Rosen said it would be a career-threatening move. I would, they said, never learn enough pediatrics to be effective. So like everyone at Harvard who needed sound advice, I went to talk it over with Dr. William B. Castle. Castle listened to my angst. Finally he asked one penetrating question.

"Tell me," he asked in that marvelous nasal New England voice, "Does the idea of going to Children's Hospital make you happy?"

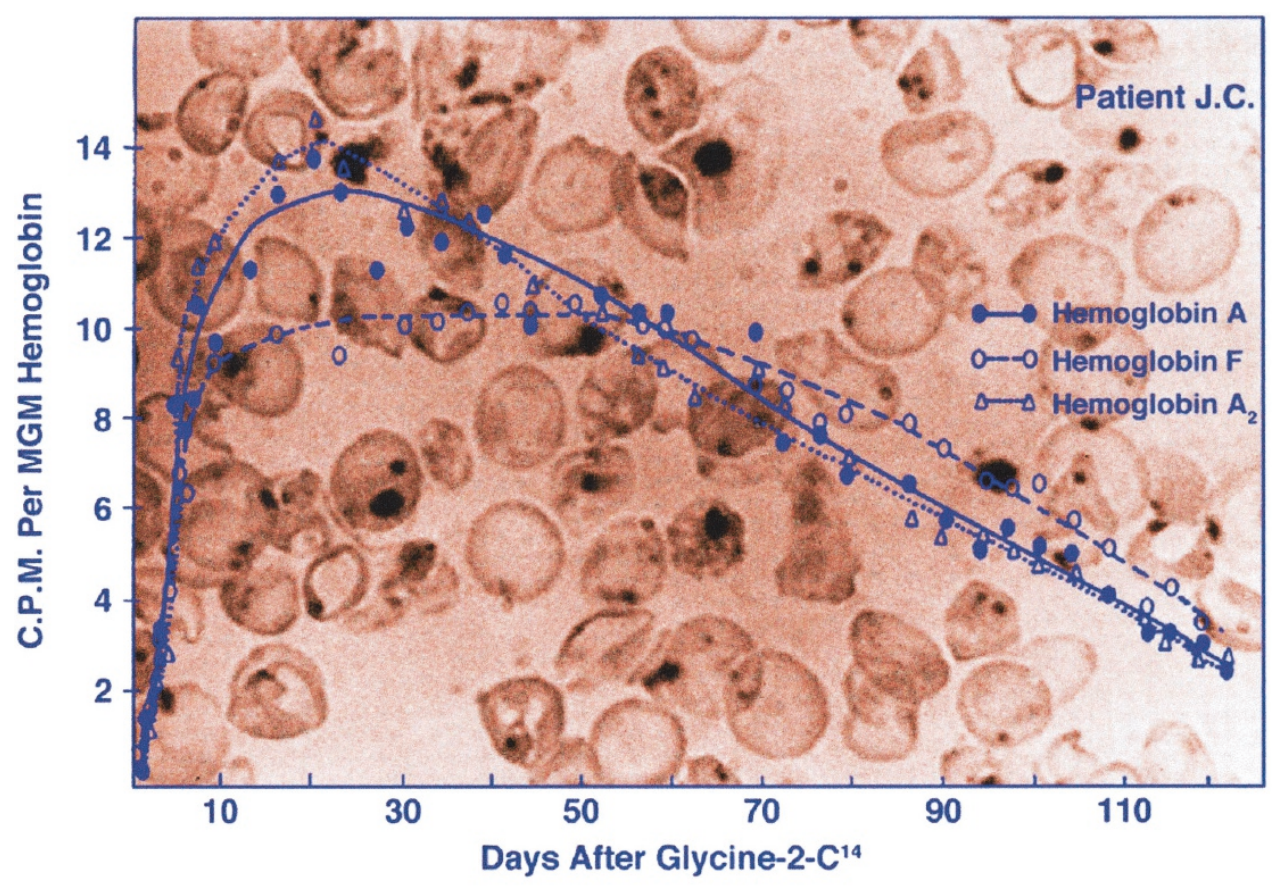

$\mathrm{SA}$ of $\mathrm{C}^{14}$ in the individual hemoglobins of patient J.C. during 122 days after injection of Glycine-2-C ${ }^{14}$.

Figure 5. The red cells of a splenectomized patient with thalassemia intermedia stained with crystal violet. Note multiple inclusions of precipitated $\alpha$ chains. The morphology is overlain by the specific activity of the patient's hemoglobins after injection of glycine-2-C14. 
"Oh yes," I responded, "that's the problem. It makes me very happy, but my friends all tell me its crazy."

"Well," he drawled, "most of the people who come to see me are unhappy. If I were you, I'd go to Children's."

Twenty-two years later, I interviewed Dr. Castle about his life in medicine. He told me that when he went to see Dr. Walter B. Cannon to tell Cannon that he, Castle, wanted to transfer from physiology to the then-new Thorndike Laboratory at the Boston City Hospital, Cannon's response was, "Ah, another brand for the burning." I think I fared much better than Castle in my quest for advice.

So my real life began. Three new fellows were there to greet me-Bill Mentzer (23), Eli Schwartz (24,25), and Bob Baehner (26-30) - among the last fellows recruited by Dr. Diamond. All three went on to distinguished careers of their own. Eli and Bob became department chairs, and there were so many more who followed them, their careers made possible by the growth of resources at Children's Hospital and, later, the joining of forces with the Dana Farber Cancer Institute, a great research and treatment facility with a focused commitment to pediatric hematology and oncology.

These excellent institutions helped us to recruit and train many remarkable young people between 1966 and 1985, when I left the leadership of the Division to become Chair of the Department of Pediatrics at Children's. Limits of time permit me to mention just a few. I present them proudly because I believe they represent the real legacy of what we tried to do. Some of our papers proved important, but most are evanescent and are replaced by the work of others. The careers of our trainees and their trainees represent the firm future of pediatrics and pediatric hematology.

Many of the early members of the training program were internists, and many had training at The National Institutes of Health. I emphasize only a few of them here. Ed Benz succeeded me as president of Dana Farber. Steve Burakoff led the Department of Pediatric Oncology at the Dana Farber for many years and recently became the Director of the NYU Cancer Center. Ed Benz, Frank Bunn (31-33), Y.W. Kan (25,34-41), Art Nienhuis $(42,43)$, and Tom Stossel (44) became presidents of the American Society of Hematology. Nienhuis is the director of St. Jude Hospital. I am very pleased that George Buchanan, one of our most outstanding pediatric trainees, became president of the American Society of Pediatric Hematology an Oncology.

Space permits me to emphasize the contributions of just a few of the pediatricians who came to the program. Herb Abelson, Harvey Cohen, Alan Ezekowitz (45), and Alan Schwartz joined Eli Schwartz and Bob Baehner to become pediatrics department chairs. Blanche Alter (46-50) and Y.W. Kan were prime movers in the prenatal diagnosis of hemoglobinopathies. Alter transferred the technology to Dimitris Loukopoulos, whose work greatly reduced the incidence of new cases of thalassemia in Greece (51). Alter went on to make important contributions to our understanding of the fetal switch (52-54). Nancy Andrews has unfolded many of the important pathways of iron metabolism, and Alan D'Andrea has revealed many of the secrets of Fanconis anemia. Larry Boxer and Mary Dinauer studied granulocyte dysfunction with distinction and went on to their fine careers in Michigan and Indiana, while Eva Guinan (55-58), Robbie Parkman (59-63), and Bruce Camitta (64-69) made important contributions to our understanding of the pathophysiology and treatment of marrow failure. Bert Lubin (70,71), Steve Feig (72-76), Bert Glader (12-14), Bill Mentzer (23,77), Orah Platt (78), and George Segal $(73,75)$ did valuable work on disorders of red cells. Barbara Miller (79-83) dissected genetic programs that are responsible for increased fetal $\mathrm{Hb}$ in certain sickle cell syndromes. Orah Platt (22) was the first to use hydroxyurea to raise fetal $\mathrm{Hb}$ in patients with sickle cell disease and explored a fascinating case of exercise induced xerocytosis (78). Nancy Olivieri $(84,85)$ became one of the world's leading clinical investigators in thalassemia. Steve Sallan (86-89), our first fellow from Puerto Rico, Luis Clavell (89), and several other trainees made enormous contributions to the treatment of childhood leukemia; Susan Shurin (90) and Richard Propper (90-92) developed effective deferoxamine therapy to prevent iron overload. Colin Sieff (93-99) and Jeffrey Lipton (100103) began our effort to understand the complexities of hematopoiesis, and David Williams (104), the first to insert a gene into the hematopoietic stem cells of a mammal, became the leader of hematology and oncology in Cincinnati.

Fortune truly smiled when Sam Lux and Stuart Orkin (48,105-108) joined our division over 25 years ago. They have each made major contributions of their own and have received many prizes for their work. Both have won the Mead Johnson award, as have Larry Boxer, Alan Schwartz, David Williams, Alan D'Andrea, and Nancy Andrews (109). Sam and Stuart are committed to the traditions that Janeway and Diamond established for us. When I moved from the leadership of the division 18 years ago to become chair of pediatrics and subsequently president of Dana Farber, I left the leadership of Children's and DFCI hematology and oncology in their totally competent hands. Now they share responsibility for a research program of 55,000 square feet of space and an annual research budget of more than \$26 million per year. To my great satisfaction, Sam is now the Robert A Stranahan Professor of Pediatrics, my former chair, and Stuart is the David G. Nathan Professor of Pediatrics and Chief of Pediatric Oncology at Dana Farber. I could not have left my precious field in better hands.

My own inspiration has continued to come from patients like the one shown in the faded photograph taken 34 years ago and shown in Fig. 6. Khaled has severe $\beta$ thalassemia and was 6 years old when this photograph was taken. When he first saw me, he had a $\mathrm{Hb}$ of 1.5 and had broken nearly every bone in his body because the enormous rate of ineffective erythropoiesis expands the medullary cavity and so weakens the bones. During the past 34 years, our division has devoted a vast amount of attention to him and children like him, and other centers have made critically important contributions to our understanding of the disease. Chelation therapy with deferoxamine has kept him alive while we try to find better solutions through clinical research. Ten years ago, he celebrated his 30th birthday at his brother's wedding. To greet that milestone, I wrote a book about him and his disease called Genes, Blood and Courage (110). Last year we celebrated his 40th. Now we are working on a new oral iron chelator for Khaled and the 


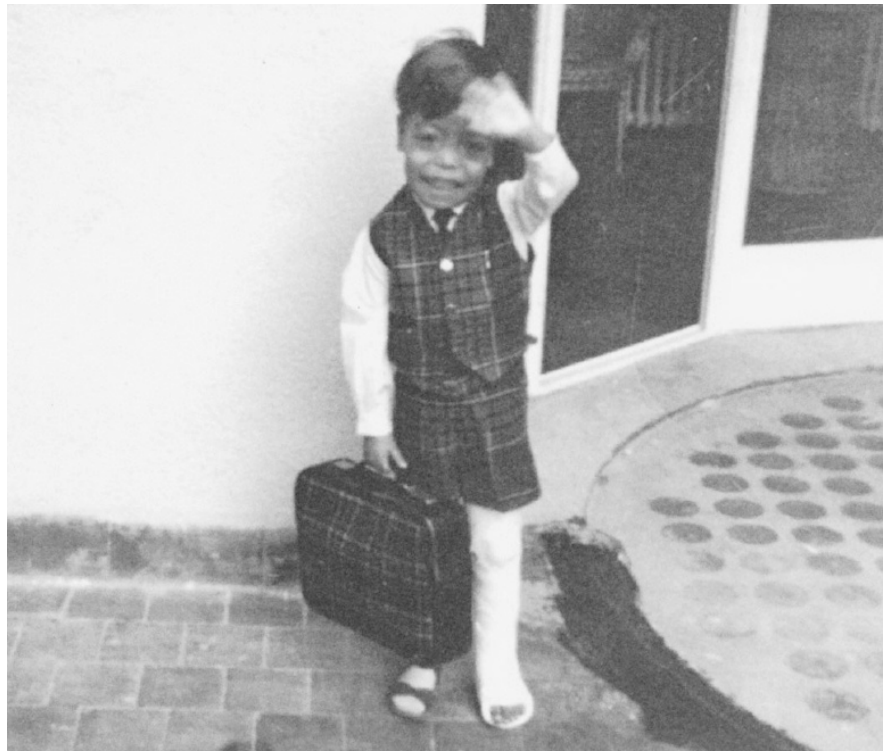

Figure 6. Khaled when he was 6 years old and arrived with a $\mathrm{Hb}$ of $1.5 \mathrm{~g} / 100$ $\mathrm{mL}$. Used by permission.

others who have waited for so long. ICL670 (Fig. 7) is a Novartis product and is in its developmental phase (111), but it looks very promising. A single dose of $20 \mathrm{mg} \cdot \mathrm{kg}^{-1} \cdot \mathrm{d}^{-1}$ removes body iron and remains detectable in the blood for $24 \mathrm{~h}$, where it chelates free iron and probably protects the heart. If its toxicity is reasonable, it will prove to be a much better drug than deferoxamine. Although I worked hard on deferoxamine, I will be very glad to see it go. Meanwhile, others are working on stem cell transplantation and even gene therapy. Clinical research is an ever exciting challenge.

Dr. Diamond told me that the joy of pediatrics is the care of kids like Khaled-watching them grow and giving them the chance to make it on their own. Truer words were never said.

The Howland Award is a great honor for any pediatrician. To receive it is to wonder how it all happened. I know why this has happened to me. First of all, I have had wonderful fellows. They have been committed to children and our field and have done great work, and they have had the benefit of the astound-

\section{ICL670 Molecular structure}
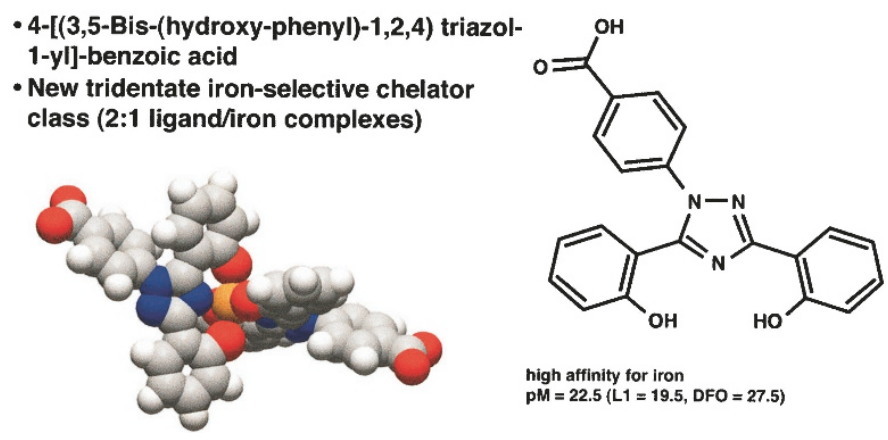

high affinity for iron $\mathrm{PM}=22.5(\mathrm{~L} 1=19.5, \mathrm{DFO}=27.5)$

Figure 7. The molecular structure of ICL670 (courtesy of Dr. Daniele Alberti and Novartis SA). Used by permission. ing growth of financial commitment to the field by federal and private sources. Second, I have had the assistance of Sam and Stuart, two of the finest hematologists in the world. Third, I have recognized that clinical research demands multidisciplinary collaboration. I have had enormous help from colleagues in the basic sciences at Harvard and at MIT. I am particularly grateful to Drs. David Baltimore, David Housman (112), Harvey Lodish (38,113-115), and Philip Sharp of MIT, who recognized the important potential of molecular biology in pediatric research and devoted as much energy as possible to the training of my fellows and junior faculty so that we could, together, move the field. I have also enjoyed a multidecade collaboration with David Weatherall and his great colleagues at Oxford $(80,106,107,116-118)$. They have been important contributors to my research efforts and to my recent focus on the management of clinical research.

Clinical research is said to be in a troubled period, and I have worked to help it so that others can enjoy the field as I have enjoyed it. No one can know enough to do important clinical research alone. One needs a committed academic health center; a devoted department of pediatrics; and the commitment of the National Institutes of Health, private foundations, and industry. And the field needs colleagues of all disciplines who share the vision. I have had all of that, and I have shared responsibility for the supervision of houseofficers and junior faculty with physician-teachers of the quality of Fred Lovejoy. Above all, I have had role models like Charles Janeway, Louis Diamond, and William Castle. They are gone now, but they live on in us. I have tried to grasp the torch from them and hand it on to others. I hope John Howland, who started this tradition, is pleased. We have all been traveling the path that he created. Today we remember him and honor his memory. That I have been selected to be part of that honor means more to me than I can fully express.

I deeply thank the American Pediatric Society for welcoming another apostate internist and then bestowing this, its highest award, on me. I salute you and all of my colleagues in pediatric research. Thank you.

\section{REFERENCES}

1. Starr P 1983 Social Transformation of American Medicine: The Rise of a Sovereign Profession and the Making of a Vast Industry. Basic Books

2. Science, the Endless Frontier: A Report to the President by V. Bush, Director of the Office of Scientific Research and Development. US Government Printing Office, Washington, DC, 1945

3. Nathan DG 1998 Clinical research: perceptions, reality and proposed solutions. JAMA 280:1427-1431

4. Eraklis AJ, Kevy SV, Diamond LK, Gross RE 1967 Hazard of overwhelming infection after splenectomy in childhood. N Engl J Med 276:1225-1229

5. Oski FA, Nathan DG, Sidel VW, Diamond LK 1964 Extreme hemolysis and red-cell distortion in erythrocyte pyruvate kinase deficiency. I. Morphology erythrokinetics and family enzyme studies. N Engl J Med 270:1023-1030

6. Nathan DG, Oski FA, Sidel VW, Diamond LK 1965 Extreme hemolysis and red cell distortion in erythrocyte pyruvate kinase deficiency. II. Measurements of erythrocyte glucose consumption, potassium flux and adenosine triphosphate stability. N Engl J Med 272:118-123

7. Nathan DG, Oski FA, Miller DR, Gardner FH 1968 Life span and organ sequestration of the red cells in pyruvate kinase deficiency. N Engl J Med 278:73-81

8. Zarkowsky HS, Oski FA, Sha-afi E, Shohet SB, Nathan DG 1968 Congenital hemolytic anemia with high sodium, low potassium red cells. I. Studies of membrane permeability. N Engl J Med 278:573-581

9. Oski FA, Naiman JL, Blum SF, Zarkowsky HS, Whaum J, Shohet SB, Green A, Nathan DG 1969 Congenital hemolytic anemia with high-sodium low-potassium red cells. Studies of three generations of a family with a new variant. N Engl J Med 290:909-916 
10. Nathan DG 1997 A memory of Frank A. Oski. Curr Opin Pediatr 9:3

11. Nathan DG, Shohet SB 1970 Erythrocyte ion transport defects and hemolytic anemia: "hydrocytosis" and "desiccytosis." Semin Hematol 7:381-408

12. Glader BE, Fortier N, Albala MM, Nathan DG 1974 Congenital hemolytic anemia associated with dehydrated erythrocytes and increased potassium loss. N Engl J Med 291:491-496

13. Glader BE, Lux SE, Muller-Soyano A, Platt OS, Propper RD, Nathan DG 1978 Energy reserve and cation composition of irreversibly sickled cells in vivo. $\mathrm{Br} J$ Haematol 40:527-532

14. Glader BE, Nathan DG 1978 Cation permeability alterations during sickling: relationship to cation composition and cellular hydration of irreversibly sickled cells Blood. 51:983-989

15. Nathan DG, Orkin SH, Ginsburg D, Look A 2003 Nathan and Oski's Hematology of Infancy and Childhood, 6th Ed. W.B. Saunders, Philadelphia

16. Nathan DG, Gunn RB 1966 Thalassemia: the consequences of unbalanced hemoglobin synthesis. Am J Med 41:815-830

17. Gabuzda TH, Nathan DG, Gardner FH 1962 Comparative metabolism of haemoglobins $\mathrm{A}$ and $\mathrm{F}$ in thalassaemia. Nature 196:781-782

18. Gabuzda TG, Nathan DG, Gardner FH 1963 The turnover of hemoglobins A, F, and A2 in the peripheral blood of three patients with thalassemia. J Clin Invest $42: 1678-1688$

19. Gabuzda TG, Nathan DG, Gardner FH 1965 The metabolism of the individua C14-labelled hemoglobins in patients with $\mathrm{H}$-thalassemia, with observations on radiochromate binding to the hemoglobins during red cell survival. J Clin Invest $44: 315-325$

20. Gabuzda TG, Nathan DG, Gardner FH 1967 Hemoglobin F and beta thalassemia. Science 157:1079

21. Letvin NL, Linch DC, Beardsley GP, McIntyre KW, Nathan DG 1984 Augmentation of fetal-hemoglobin production in anemic monkeys by hydroxyurea. N Eng J Med 310:869-873

22. Platt OS, Orkin SH, Dover G, Beardsley GP, Miller B, Nathan DG 1984 Hydroxyurea enhances fetal hemoglobin production in sickle cell anemia. J Clin Inves 74:652-656

23. Mentzer WC, Baehner RL, Schmidt-Schonbein H, Robinson SH, Nathan DG 197 Selective reticulocyte destruction in erythrocyte pyruvate kinase deficiency. J Clin Invest 50:688-699

24. Schwartz E, Smith D, Nathan DG 1967 Loci of human haemoglobin genes. Lancet 2:1422-1423

25. Kan YW, Schwartz E, Nathan DG 1968 Globin chain synthesis in the alpha thalassemia syndromes. J Clin Invest 47:2512-2522

26. Baehner RL, Nathan DG 1967 Leukocyte oxidase: defective activity in chronic granulomatous disease. Science 155:835-836

27. Baehner RL, Nathan DG 1968 Quantitative nitroblue tetrazolium test in chronic granulomatous disease. N Engl J Med 278:971-976

28. Baehner RL, Nathan DG, Karnovsky ML 1970 Correction of metabolic deficiencies in the leukocytes of patients with chronic granulomatous disease. J Clin Invest 49:865-870

29. Baehner RL, Nathan DG, Castle WB 1971 Oxidant injury of Caucasian glucose-6 phosphate dehydrogenase-deficient red blood cells by phagocytosing leukocytes during infection. J Clin Invest 50:2466-2473

30. Nathan DG, Baehner RL, Weaver DK 1969 Failure of nitroblue tetrazolium reduction in phagocytic vacuoles of leukocytes in chronic granulomatous disease. J Clin Invest 48:1895-1904

31. Jensen MC, Bunn HF, Halikas GC, Nathan DG 1972 Oxygen affinity independent action of cyanate and 2,3, DPG on sickling. Adv Exp Med Biol 28:297-302

32. Jensen M, Bunn HF, Halikas G, Kan YW, Nathan DG 1973 Effects of cyanate an 2,3-diphosphoglycerate on sickling. Relationship to oxygenation. J Clin Invest 52:2542-2547

33. Jensen MC, Nathan DG, Bunn HF 1973 The reaction of cyanate with the alpha and beta subunits in hemoglobin: effects of oxygenation, phosphates and carbon dioxide. J Biol Chem 248:8057-8063

34. Kan YW, Nathan DG 1968 Beta thalassemia trait: detection at birth. Science 161:589-590

35. Kan YW, Nathan DG 1970 Mild thalassemia: the result of interactions of alpha and beta thalassemia genes. J Clin Invest 49:635-642

36. Kan YW, Dozy AM, Alter BP, Frigoletto FD, Nathan DG 1972 Detection of the sickle gene in the human fetus. N Engl J Med 287:1-5

37. Kan YW, Forget BG, Nathan DG 1972 Gamma-beta thalassemia: a cause of hemolytic disease of the newborn. N Engl J Med 286:129-134

38. Kan YW, Nathan DG, Lodish HF 1972 Equal synthesis of a- and b-globin chains in erythroid precursors in heterozygous thalassemia. J Clin Invest 51:1906-1909

39. Kan YW, Nathan DG, Cividalli G, Crookston MC 1974 Concentration of fetal red blood cells from a mixture of maternal and fetal blood by anti-i serum - an aid to prenatal diagnosis of hemoglobinopathies. Blood 43:411-415

40. Kan YW, Nathan DG, Cividalli G, Frigoletto F 1974 Intrauterine diagnosis of thalassemia. Ann NY Acad Sci 232:145-151

41. Cividalli G, Nathan DG, Kan YW, Santamarina B, Frigoletto FD 1974 Relation of beta to gamma synthesis during the first trimester: an approach to prenatal diagnosis of thalassemia. Pediatr Res 8:553-560

42. McDonagh KT, Dover GJ, Donahue RE, Nathan DG, Agricola B, Byrne E, Nienhuis AW 1992 Hydroxyurea-induced $\mathrm{HbF}$ production in anemic primates: augmentation by erythropoietin, hematopoietic growth factors, and sodium butyrate. Exp Hemato 20:1156-1164

43. Nienhuis AW, Donahue RE, Karlsson S, Clark SC, Agricola B, Antinoff N, Pierce JE, Turner P, Anderson WF, Nathan DG 1987 Recombinant human granulocytemacrophage colony-stimulating factor (GM-CSF) shortens the period of neutropenia after autologous bone marrow transplantation in a primate model. J Clin Invest 80:573-577

44. Nathan DG, Stossel TP, Gunn RB, Zarkowsky HS, Laforet MT 1969 Influence of hemoglobin precipitation on erythrocyte metabolism in alpha and beta thalassemia J Clin Invest 48:33-41

45. Ezekowitz RA, Sieff CA, Dinauer MC, Nathan DG, Orkin SH 1990 Restoration of phagocyte function by interferon gamma in X-linked chronic granulomatous disease occurs at the level of a progenitor cell. Blood 76:2443-2448

46. Alter BP, Friedman S, Hobbins JC, Mahoney MJ, Sherman AS, McSweeney JF, Schwartz E, Nathan DG 1976 Prenatal diagnosis of sickle cell anemia and alpha G Philadelphia: study of a fetus also at risk for $\mathrm{Hb} \mathrm{S} / \beta+$-thalassemia. $\mathrm{N}$ Engl J Med 294:1040-1041

47. Alter BP, Nathan DG, Modell CB, Fairweather D, Mahoney MJ, Hobbins JC 1977 Prenatal diagnosis of hemoglobinopathies: detection of alpha thalassemia trait and of sickle cell disease in utero. Hemoglobin 1:395-400

48. Orkin SH, Alter BP, Altay C, Mahoney MJ, Lazarus H, Hobbins JC, Nathan DG 1978 Application of endonuclease mapping to the analysis and prenatal diagnosis of thalassemias caused by globin gene deletion. N Engl J Med 299:166-172

49. Alter BP, Orkin SH, Forget BG, Nathan DG 1980 Prenatal diagnosis of hemoglobinopathies: the New England approach. Ann NY Acad Sci 344:151-164

50. Li FP, Alter BP, Nathan DG 1972 The mortality of acquired aplastic anemia in children. Blood 40:153-162

51. Loukopoulos D, Antsaklis A, Aleporou-Marinou V, Panourgias J, Karababa P, Fessas P 1982 Prenatal diagnosis of beta-thalassemia; the Greek experience. Birth Defects Orig Artic Ser 18:293-301

52. Alter BP, Rappeport JM, Huisman TH, Schroeder WA, Nathan DG 1976 Fetal erythropoiesis following bone marrow transplantation. Blood 48:843-853

53. Alter BP, Jackson BT, Lipton JM, Piasecki GJ, Jackson PL, Kudish M, Nathan DG 1981 Control of the simian fetal hemoglobin switch at the progenitor cell level. J Clin Invest 67:458-466

54. Alter BP, Nathan DG 1982 A cellular model for hemoglobin switching. Birth Defects Orig Artic Ser 18:111-116

55. Guinan EC, Lee YS, Lopez KD, Kohler S, Oette DH, Bruno E, Kozakewich H, Nathan DG, Hoffman R 1993 Effects of interleukin-3 and granulocyte-macrophage colony-stimulating factor on thrombopoiesis in congenital amegakaryocytic thrombocytopenia. Blood 81:1691-1698

56. Guinan EC, Lopez KD, Huhn RD, Felser JM, Nathan DG 1994 Evaluation of granulocyte-macrophage colony-stimulating factor for treatment of pancytopenia in children with Fanconi anemia. J Pediatr 124:144-150

57. Janov AJ, Leong T, Nathan DG, Guinan EC 1996 Diamond-Blackfan anemia Natural history and sequelae of treatment. Medicine 75:77-78

58. Guinan E, Sieff CA, Oette DH, Nathan DG 1990 A phase I/II trial of recombinan granulocyte-macrophage colony stimulating factor for children with aplastic anemia. Blood 76:1077-1082

59. Parkman R, Rappeport J, Camitta B, Levey RH, Nathan DG 1978 Successful use of multiagent immunosuppression in the bone marrow transplantation of sensitized patients. Blood 52:1163-1169

60. Parkman R, Rappeport J, Geha R, Belli J, Cassady R, Levey R, Nathan DG, Rosen FS 1978 Complete correction of the Wiskott-Aldrich syndrome of allogeneic bone-marrow transplantation. N Engl J Med 298:921-927

61. Parkman R, Rappeport J, Hellman S, Lipton JM, Smith B, Geha R, Nathan DG 1984 Busulfan and total body irradiation as antihematopoietic stem cell agents in the preparation of patients with congenital bone marrow disorders for allogeneic bone marrow transplantation. Blood 64:852-857

62. Smith BR, Guinan EC, Parkman R, Ferrara J, Levey RH, Nathan DG, Rappeport JM 1985 Efficacy of a cyclophosphamide-procarbazine-antithymocyte serum regimen for prevention of graft rejection following bone marrow transplantation for transfused patients with aplastic anemia. Transplantation 39:671-673

63. Smith BR, Parkman R, Lipton J, Nathan DG, Rappeport JM 1985 Efficacy of a short course (four doses) of methotrexate following bone marrow transplantation for prevention of graft-versus-host disease. Transplantation 39:326-329

64. Camitta BM, Nathan DG, Forman EN, Parkman R, Rappeport JM, Orellana TD 1974 Post-hepatitic aplastic anemia - an indication for early bone marrow transplantation. Blood 43:473-483

65. Camitta BM, Thomas ED, Nathan DG, Gale RP, Kopecky KJ, Rappeport JM, Santos G, Gordon-Smith EC, Storb R 1979 A prospective study of androgens and bone marrow transplantation for treatment of severe aplastic anemia. Blood 53:504-514

66. Camitta BM, Rappeport JM, Parkman R, Nathan DG 1975 Selection of patients for bone marrow transplantation in severe aplastic anemia. Blood 45:355-363

67. Camitta BM, Thomas ED, Nathan DG, Santos G, Gordon-Smith EC, Gale RP, Rappeport JM, Storb R 1976 Severe aplastic anemia: a prospective study of the effect of early marrow transplantation on acute mortality. Blood 48:63-70

68. Camitta B, Rappeport J, Parkman R, Nathan DG 1980 Bone marrow transplantation for severe aplastic anemia in children. Am J Pediatr Hematol Oncol 2:145-153

69. Camitta B, O'Reilly RJ, Sensenbrenner L, Rappeport J, Champlin R, Doney K, August C, Hoffman RG, Kirkpatrick D, Stuart R, Santos G, Parkman R, Gale RP, Storb R, Nathan DG 1983 Antithoracic duct lymphocyte globulin therapy of severe aplastic anemia. Blood 62:883-888

70. Lubin BH, Baehner RL, Schwartz E, Shohet SB, Nathan DG 1971 The red cell peroxide hemolysis test in the differential diagnosis of obstructive jaundice in the newborn period. Pediatrics 48:562-565

71. Lubin BH, Shohet BG, Nathan DG 1972 Changes in fatty acid metabolism after erythrocyte peroxidation: stimulation of membrane repair process. J Clin Invest $51: 338-344$ 
72. Feig SA, Nathan DG, Zarkowsky HS, Gerald PS 1972 Congenital methemoglobinemia: the result of age-dependent decay of methemoglobin reductase. Blood 39:407414

73. Segel GB, Feig SA, Mentzer WC, McCaffrey RP, Wells R, Bunn HF, Shohet SB, Nathan DG 1972 Effects of urea and cyanate on sickling in vitro. N Engl J Med 287:59-64

74. Feig SA, Segal GB, Shohet SB, Nathan DG 1972 Energy metabolism in human erythrocytes. II. Effects of glucose depletion. J Clin Invest 51:1547-1554

75. Segel GB, Feig SA, Glader BE, Muller A, Dutcher P, Nathan DG 1975 Energy metabolism in human erythrocytes: the role of phosphoglycerate kinase in cation transport. Blood 46:271-278

76. Feig SA, Shohet SB, Nathan DG 1971 Energy metabolism in human erythrocytes. I. Effects of sodium fluoride. J Clin Invest 50:1731-1737

77. Rosenthal A, Mentzer WC, Eisenstein EB, Nathan DG, Nelson NM, Nadas AS 1971 The role of red blood cell organic phosphates in adaptation to congenital heart disease. Pediatrics 47:537-547

78. Platt OS, Lux SE, Nathan DG 1981 Exercise-induced hemolysis in xerocytosis: erythrocyte dehydration and shear sensitivity. J Clin Invest 68:631-638

79. Miller BA, Lipton JM, Linch DC, Burakoff SJ, Nathan DG 1985 THY-1 is a differentiation antigen that characterizes immature murine erythroid and myeloid hematopoietic progenitors. J Cell Physiol 123:25-32

80. Miller BA, Salameh S, Ahmed M, Wainscoat J, Antognetti G, Orkin S, Weatheral D, Nathan DG 1986 High fetal hemoglobin production in sickle cell anemia in the eastern province of Saudi Arabia is genetically determined. Blood 67:1404-1410

81. Miller BA, Olivieri N, Salameh M, Ahmed GA, Antognetti G, Huisman THJ, Nathan DG, Orkin S 1987 Molecular analysis of the high-hemoglobin-F phenotype in Saudi Arabian sickle cell anemia. N Engl J Med 316:244-250

82. Miller BA, Platt O, Hope S, Dover G, Nathan DG 1987 Influence of hydroxyurea on fetal hemoglobin production in vitro. Blood 70:1824-1829

83. Miller BA, Salameh M, Ahmed M, Olivieri N, Antognetti G, Orkin SH, Huisman TH, Nathan DG 1987 Analysis of hemoglobin F production in Saudi Arabian families with sickle cell anemia. Blood 70:716-720

84. Wolfe L, Olivieri N, Sallan D, Colan S, Rose V, Propper R, Freedman MH, Nathan DG 1985 Prevention of cardiac disease by subcutaneous deferoxamine in patients with thalassemia major. N Engl J Med 312:1600-1603

85. Olivieri NF, Nathan DG, MacMillan JH, Wayne AS, Liu PP, McGee A, Martin M, Korean G, Cohen AR 1994 Survival in medically treated patients with homozygous $\beta$-thalassemia. N Engl J Med 331:574-578

86. Sallan SE, Camitta BM, Cassady FR, Nathan DG, Frei E III 1978 Intermittent combination chemotherapy with adriamycin for childhood acute lymphoblastic leukemia. Blood 51:425-433

87. Sallan SE, Weinstein HJ, Nathan DG 1981 The childhood leukemias. J Pediatr 99:676-688

88. Sallan SE, Hitchcock BS, Gelber R, Cassady JR, Frei E III, Nathan DG 1983 Influence of intensive asparaginase in the treatment of childhood non-T-cell acute lymphoblastic leukemia. Cancer Res 43:5601-5607

89. Ritz J, Sallan SE, Bast RC Jr, Lipton JM, Clavell LA, Feeney M, Hercend T, Nathan DG, Schlossman SF 1982 Autologous bone marrow transplantation in CALLA positive acute lymphoblastic leukemia after in vitro treatment with $\mathrm{J} 5$ monoclonal antibody and complement. Lancet 2:60-63

90. Propper RD, Shurin SB, Nathan DG 1976 Reassessment of the use of desferrioxamine B in iron overload. N Engl J Med 294:1421-1423

91. Propper RD, Cooper B, Rufo R, Nienhuis AW, Anderson WF, Bunn HF, Rosentha A, Nathan DG 1977 Continuous subcutaneous administration of desferrioxamine in patients with iron overload. N Engl J Med 297:418-423

92. Propper RD, Button LN, Nathan DG 1980 New approaches to the transfusion management of thalassemia. Blood 55:55-60

93. Sieff CA, Emerson SE, Donahue RE, Nathan DG, Wang EA, Wong GG, Clark SC 1985 Human recombinant granulocyte-macrophage colony-stimulating factor: a multilineage hematopoietin. Science 230:1171-1173

94. Sieff CA, Emerson SG, Mufson A, Gesner TG, Nathan DG 1986 The dependence of highly enriched human bone marrow progenitors on hemopoietic growth factors and their response to recombinant erythropoietin. J Clin Invest 77:74-81

95. Sieff CA, Niemeyer CM, Nathan DG, Ekern SC, Beiber FR, Yang Y-C, Wong G, Clark SC 1987 Stimulation of human hematopoietic colony formation by recombinant gibbon multi-colony-stimulating factor or interleukin 3. J Clin Invest 80:818-823
96. Sieff CA, Ekern SC, Nathan DG, Anderson JW 1989 Combinations of recombinant colony-stimulating factors are required for optimal hematopoietic differentiation in serum-deprived culture. Blood 73:688-693

97. Jubinsky PT, Krijanoski OI, Nathan DG, Tavernier J, Sieff CA 1997 The beta chain of the interleukin-3 receptor functionally associates with the erythropoietin receptor. Blood 90:1867-1873

98. Rebel VI, Tanaka M, Lee J-S, Hartnett S, Pulsipher M, Nathan DG, Mulligan RC, Sieff CA 1999 One-day ex vivo culture allows effective gene transfer into human nonobese diabetic/severe combined immune-deficient repopulating cells high titer vesicular stomatitis virus $\mathrm{G}$ protein pseudotyped retrovirus. Blood 93:2217-2224

99. Gazda H, Lipton JM, Willig TN, Ball S, Niemeyer CM, Tchernia G, Mohandas N, Daly MJ, Ploszynska A, Orfali KA, Vlachos A, Glader BE, Rokicka-Milewska R, Ohara A, Baker D, Pospisilova D, Webber A, Viskochil DH, Nathan DG, Beggs AH Sieff CA 2001 Evidence for linkage of familial diamond-blackfan anemia to chromosome 8p23.3-p22 and for non-19q non-8p disease. Blood 97:2145-2150

100. Lipton JM, Link NA, Breard J, Jackson PL, Clarke BJ, Nathan DG 1980 Monocytes do not inhibit peripheral blood erythroid burst forming unit colony formation. J Clin Invest 65:219-223

101. Lipton JM, Reinherz EL, Kudisch M, Jackson PL, Schlossman SF, Nathan DG 1980 Mature bone marrow erythroid burst-forming units (BFU-E) do not require T-cells for induction of erythropoietin-dependent differentiation. J Exp Med 152:350-360

102. Lipton JM, Kudisch M, Nathan DG 1981 Response of three classes of human erythroid progenitors to the absence of erythropoietin in vitro as a measure of progenitor maturity. Exp Hematol 9:1035-1041

103. Lipton JM, Nadler LM, Canellos GP, Kudisch M, Reiss CS, Nathan DG 1983 Evidence for genetic restriction in the suppression of erythropoiesis by a unique subset of T-lymphocytes in man. J Clin Invest 72:694-706

104. Williams DA, Lemischka IR, Nathan DG, Mulligan RC 1984 Introduction of a new genetic material into pluripotent haematopoietic stem cells of the mouse. Nature $310: 476-480$

105. Orkin SH, Nathan DG 1976 The thalassemias. N Engl J Med 295:710-714

106. Orkin SH, Old J, Lazarus H, Altay C, Gurgey A, Weatherall DJ, Nathan DG 1979 The molecular basis of alpha-thalassemias: frequent occurrence of nondeletion defects among non-Asians with $\mathrm{HbH}$ disease. Cell 17:33-42

107. Orkin SH, Old J, Weatherall DJ, Nathan DG 1979 Partial deletion of beta globin gene DNA in certain patients with beta thalassemia. Proc Natl Acad Sci USA $76: 2400-2404$

108. Orkin SH, Goff SC, Nathan DG 1981 Heterogeneity of DNA deletion in gamma delta beta-thalassemia. J Clin Invest 67:878-884

109. Parsons SK, Fleming MD, Nathan DG, Andrews NC 1996 Iron deficiency anemia associated with an error or iron metabolism in two siblings: a thirty year follow up. Hematology 1:65-73

110. Nathan DG 1995 Genes, Blood, and Courage. A Boy called Immortal Sword. The Belknap Press of Harvard University Press, Cambridge

111. Nisbet-Brown E, Olivieri NF, Giardina PJ, Grady RW, Neufeld EJ, Sechaud R, Krebs-Brown AJ, Anderson JR, Alberti D, Sizer KC, Nathan DG 2003 Effectivenes and safety of ICL670 in iron-loaded patients with thalassaemia: a randomised double-blind, placebo-controlled, dose-escalation trial. Lancet 361:1597-1602

112. Nathan DG, Hillman DG, Chess L, Alter BP, Clarke BJ, Breard J, Housman DE 1978 Normal erythropoietic helper T-cells in congenital hypoplastic (DiamondBlackfan) anemia. N Engl J Med 298:1049-1051

113. Lodish HF, Nathan DG 1972 Regulation of hemoglobin synthesis: preferential inhibition of alpha and beta globin synthesis. J Biol Chem 247:7822-7829

114. Cividalli G, Nathan DG, Lodish HF 1974 Translational control of hemoglobin synthesis in thalassemic bone marrow. J Clin Invest 53:955-963

115. Nathan DG, Lodish HL, Kan YW, Housman DG 1971 Beta thalassemia and translation of globin messenger RNA. Proc Natl Acad Sci USA 68:2514-2518

116. Nathan DG, Weatherall DJ 1998 Iron chelation with oral deferiprone in patients with thalassemia. N Engl J Med 1711-1712

117. Nathan DG, Weatherall DJ 1999 Academia and industry: lessons from the unfortunate events in Toronto. Lancet 353:771-772

118. Nathan DG, Weatherall DJ 2002 Academic freedom in clinical research. N Eng J Med 347:1368-1371 